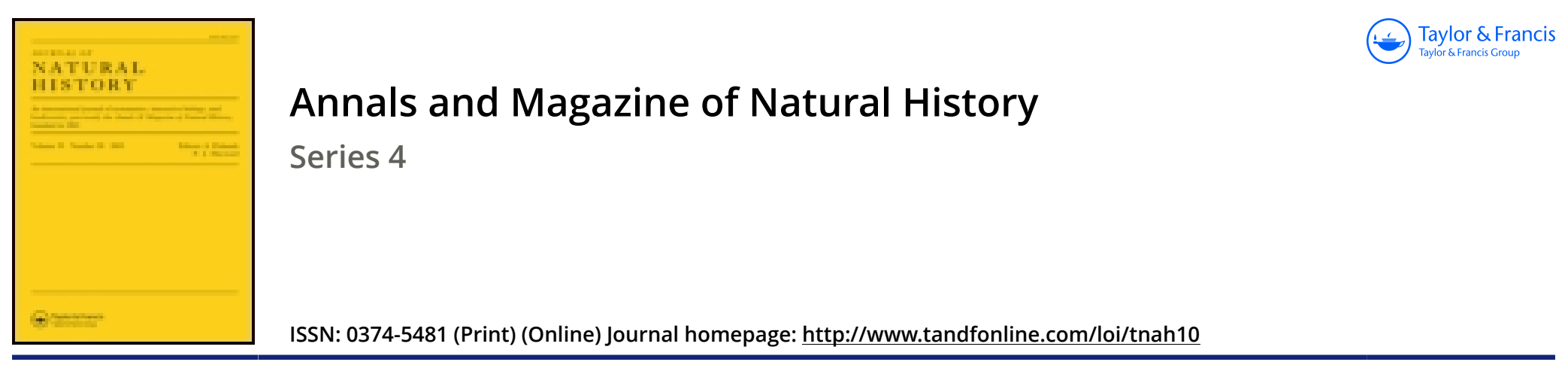

\title{
Note on the femoral brushes of the Mantidæ
}

\section{Prof. J. Wood-Mason}

To cite this article: Prof. J. Wood-Mason (1877) Note on the femoral brushes of the Mantidæ, Annals and Magazine of Natural History, 19:111, 269-269, DOI: 10.1080/00222937708682133

To link to this article: http://dx.doi.org/10.1080/00222937708682133

$$
\text { 曲 Published online: } 13 \text { Oct } 2009 .
$$

Submit your article to this journal ¿

Џll Article views: 4

Q View related articles $\asymp$ 
referred, with some doubt, to the genus Mauisaurus of Dr. Hector, founded upon a Saurian from the Cretaceons formation of New Zealand. He gave it the name of Mauisaurus Gardneri in honour of its discoverer. A small heap of pebbles was found in the neighbourhood of the ribs; and it was supposed that these had been contained in the stomach of the animal.

\section{MISCELLANEOUS.}

\section{Note on the Femoral Brushes of the Mantidæ.}

By Prof. J. Wood-Mason.

Since the abstract $*$ of my paper on these structures and their use was published, I have been enabled to consult M. Stal's memoir $†$ entitled "Orthoptera quædam Africana;" and I find that I have been anticipated as to the discovery-the brushes, or rather the setulose eminences which I call brushes, being thus described in a footnote to p. 382 of the work cited:- "In latere interiore femorum anticorum Mantodeorum adest apicem versus prope marginem inferiorem spatium parvum leviter convexum, oblongum, dense brevissimeque setulosum." M. Stal makes no suggestion as to the possible use of the brushes to the insects; but I have ascertained \$ that they are exclusively used for keeping the eyes and ocelli in a functional condition, and that they are present in the young when these quit the egr.

A full account of my observations and experiments on numerous living specimens belonging to several genera (Schizocephala, Pseudomantis, Hierodula, \&c.) will be given in my paper.

Calcutta, Dec. 22, 1876.

On the Development of the Antenno in the Pectinicorn Mantidæ. By Prof. J. Woon-Mason.

The anthor shows that, down to the last change of skin but one, no difference is to be detected between the two sexes of Gongylus gongylodes, either in the form or in the proportional length of the antennæ, which in both male and female are identically the same simple and setaceous structures, consisting of two distinct basilar segments followed by a multitude of very short and ill-defined flagellar ones, but that shortly after this event these appendages in the male begin to thicken throughout that portion of their length which in the perfect insect is bipectinated, so as eventually to acquire a compressed spindle-shaped form; that this thickening is the outward manifestation of the growth going on beneath the

* P. A. S. B., June 1876, p. 123 ; and this Journal, vol. xviii. p. 438.

+ CEfvers. af Kongl. Svenska Vetenskaps-Akademiens Förhandl. Stockholm, 1871 , no. 3 , sid. $375-401$.

t P. A. S. B., August 1876, p. 170. 